\title{
Superoxide-dependent formation of hydroxyl radicals in the presence of iron salts
}

\author{
Detection of 'free' iron in biological systems by using bleomycin-dependent degradation of DNA
}

John M. C. GUTTERIDGE,* David A. ROWLEY $\dagger$ and Barry HALLIWELL $\dagger$

*National Institute of Biological Standards and Control, Holly Hill, Hampstead, London NW3 6RB, U.K., and †Department of Biochemistry, King's College, University of London, Strand, London WC2R 2LS, U.K.

\section{(Received 13 May 1981/Accepted 29 June 1981)}

\begin{abstract}
Bleomycin in the presence of iron(II) degrades DNA to form a thiobarbituric acid-reactive product. This has been made the basis of a specific assay method for 'free' iron in biological fluids. Human synovial fluid, human cerebrospinal fluid and rat pleural-exudate fluid were found to contain micromolar concentrations of 'free' iron, which would be sufficient to allow formation of the hydroxyl radical from superoxide and hydrogen peroxide generated in vivo. This assay method does not detect iron bound to transport proteins or to enzymes.
\end{abstract}

Oxygen is essential for aerobic life, but it has long been known to be toxic when supplied at concentrations greater than those in normal air (Haugaard, 1968). The biochemical mechanisms responsible for $\mathrm{O}_{2}$ toxicity include lipid peroxidation and the generation of $\mathrm{H}_{2} \mathrm{O}_{2}$ together with the superoxide free radical, $\mathrm{O}_{2}^{--}$(Fridovich, 1978; Halliwell, 1978a, 1981). In the presence of traces of iron salts, $\mathrm{O}_{2}^{-\cdot}$ and $\mathrm{H}_{2} \mathrm{O}_{2}$ can react together in vitro to form the hydroxyl radical, $\mathrm{OH}^{\bullet}$, which can attack and destroy almost all known biomolecules (McCord \& Day, 1978; Halliwell, 1978b,c; Gutteridge et al., 1979). It has been suggested that most, if not all, of the toxic effects of $\mathrm{O}_{2}^{-\cdot}$ are due to the formation of $\mathrm{OH}^{\cdot}$ from it in vivo (Fridovich, 1978; Halliwell, 1978a,b,c, 1981; Diguiseppi \& Fridovich, 1980). Formation of $\mathrm{OH}^{\cdot}$ from $\mathrm{O}_{2}^{-}$and $\mathrm{H}_{2} \mathrm{O}_{2}$ requires the presence of traces of iron salts; other transition metals or iron-protein complexes such as ferritin, cytochromes, haemoglobin or catalase are unable to catalyse the reaction (Halliwell, 1978b). The only exception to this rule that has been established so far is iron-saturated lactoferrin, which can cause formation of $\mathrm{OH} \cdot$ from $\mathrm{H}_{2} \mathrm{O}_{2}$ (Ambruso \& Johnston, 1981). However, lactoferrin and other iron-binding proteins are only partially loaded with iron in normal individuals, and partially loaded lactoferrin does not cause $\mathrm{OH}^{\cdot}$ formation (J. M. C. Gutteridge, unpublished work).

If $\mathrm{OH}^{\bullet}$ is indeed responsible for the toxic effects of $\mathrm{O}_{2}^{--}$generated in vivo, then traces of iron salts must be available to catalyse formation of this reactive species. The methods available for measuring iron in body fluids and tissue extracts, such as atomicabsorption spectroscopy and colorimetric methods, measure both 'free' and protein-bound iron, however. In the present paper, we describe a sensitive and specific assay method for iron salts that can be used on biological systems and does not detect pro: tein-bound iron. It employs the anti-tumour antibiotic bleomycin, which binds to and degrades DNA. Degradation is accompanied by the formation of a product similar to malondialdehyde that reacts with thiobarbituric acid to form a chromogen (Gutteridge, 1979; Burger et al., 1980). Degradation by bleomycin is absolutely dependent on the presence of $\mathrm{Fe}^{2+}$ ions, and so the rate of degradation can be used to assess the 'free' iron content of a system. Although other metal ions can bind to bleomycin (Dabrowiak, 1980), they do not result in DNA degradation. The assay conditions have been carefully designed to prevent any interference from iron-proteins.

\section{Materials and methods}

\section{Reagents}

Calf-thymus DNA (type 1) and catalase (thymolfree) were obtained from Sigma Chemical Co. (Poole, Dorset, U.K.), Chelex-100 was from BioRad Laboratories (St. Albans, Herts, U.K.), bleomycin sulphate was from Lundbeck (Luton, Beds., U.K.), human haemoglobin (96\% pure) was from Calbiochem (Basingstoke, Hants., U.K.) and pyrogen-free water was from Travenol (Thetford, Nor- 
folk, U.K.). All other reagents were of the highest quality available from BDH Chemicals (Poole, Dorset, U.K.). Ferritin, lactoferrin and transferrin loaded with iron to a known percentage were a gift from Dr. A. Segal (University College Hospital Medical School, London W.C.1, U.K.).

\section{Assay of iron by the bleomycin method}

All reagents except for the sample under test are made up in pyrogen-free water in new plastic Universal containers and shaken with Chelex-100 to remove as much contaminating iron as possible. Ascorbic acid solution was freshly prepared by dissolving $0.7 \mathrm{~g}$ of AnalaR solid in $10 \mathrm{ml}$ of pyrogen-free water, shaking with Chelex $(0.4 \mathrm{~g})$, centrifuging to remove the Chelex and then diluting $1: 50$ with Chelex-treated pyrogen-free water. A solution containing $1 \mathrm{mg}$ of bleomycin sulphate $/ \mathrm{ml}$ was prepared by using $50 \mathrm{mg}$ of Chelex resin and centrifuged as above. To prepare the DNA solution $1 \mathrm{mg}$ of calf thymus DNA $/ \mathrm{ml}$ was mixed with $0.4 \mathrm{~g}$ of Chelex. The sample was left at $4^{\circ} \mathrm{C}$ overnight. The tube was spun at $2000 \mathrm{~g}$ to remove the resin, and the supernatant was used as the DNA substrate.

The reaction mixture contains the following reagents, added in the order stated, to new plastic metal-ion-free disposable tubes by using new plastic pipette tips: $0.5 \mathrm{ml}$ of calf thymus DNA $(1 \mathrm{mg} / \mathrm{ml})$, $0.05 \mathrm{ml}$ of bleomycin sulphate $(1 \mathrm{mg} / \mathrm{ml}), 0.1 \mathrm{ml}$ of $\mathrm{MgCl}_{2}(50 \mathrm{~mm}), 0.1 \mathrm{ml}$ of sample, $0.05 \mathrm{ml}$ of $\mathrm{HCl}$ $(10 \mathrm{mM})$, pyrogen-free water $(0.1 \mathrm{ml})$ and $0.1 \mathrm{ml}$ of ascorbic acid solution. Controls are set up with pyrogen-free water instead of the sample. Tubes are mixed before and after addition of ascorbate and then incubated at $37^{\circ} \mathrm{C}$ for $2 \mathrm{~h}$ with shaking. Then $1 \mathrm{ml}$ of $0.1 \mathrm{M}$-EDTA is added to stop the reaction, and the contents are transferred to glass tubes and then mixed with $1 \mathrm{ml}$ of $1 \%(\mathrm{w} / \mathrm{v})$ thiobarbituric acid (in $50 \mathrm{~mm}-\mathrm{NaOH}$ ) and $1 \mathrm{ml}$ of $25 \%(\mathrm{v} / \mathrm{v}) \mathrm{HCl}$. Solutions are heated at $100^{\circ} \mathrm{C}$ for $15 \mathrm{~min}$, cooled, and the chromogen is measured by its absorbance at $532 \mathrm{~nm}$.

A standard curve is prepared with $\mathrm{FeCl}_{3}$ dissolved in Chelex-treated pyrogen-free water. The $\mathrm{pH}$ optimum for the reaction is 7.3 . Addition of $0.05 \mathrm{ml}$ of $10 \mathrm{~mm}-\mathrm{HCl}$ normally brings the $\mathrm{pH}$ into this range, but the amount added might have to be varied if acidic samples are being assayed. The stimulatory effect of $\mathrm{Mg}^{2+}$ ions is observed over the concentration range $16-250 \mathrm{mM}, 50 \mathrm{~mm}$ being selected for convenience. Sensitivity can be altered by varying the time of incubation.

\section{Results}

\section{Assay procedure}

Degradation of DNA by bleomycin in the presence of $\mathrm{Fe}^{2+}$ ions generates a product that reacts with thiobarbituric acid to give a chromogen. Provided that the instructions in the Materials and methods section are followed exactly, this can be made the basis of a highly sensitive assay for iron salts, accurate in the low-micromolar range (Fig. 1). Ascorbic acid is included in the reaction mixture to reduce any $\mathrm{Fe}^{3+}$ present to $\mathrm{Fe}^{2+}$. The sensitivity of the assay can be varied by altering the time of incubation of the sample with the bleomycin mixture, although a time of $2 \mathrm{~h}$ was normally used in our experiments. Some biological fluids and extracts might undergo lipid peroxidation during such a prolonged incubation, producing substances that react with thiobarbituric acid to give a chromogen that also absorbs at $532 \mathrm{~nm}$. This can be corrected for by using additional controls from which bleomycin has been omitted. Such controls have been performed for all the results listed in the present paper, although corrections were not found to be necessary with the fluids that we used. Bleomycin itself does not increase lipid peroxidation in biological fluids (J. M. C. Gutteridge, unpublished work).

Normal laboratory distilled water was sometimes found to contain variable amounts of iron salts as

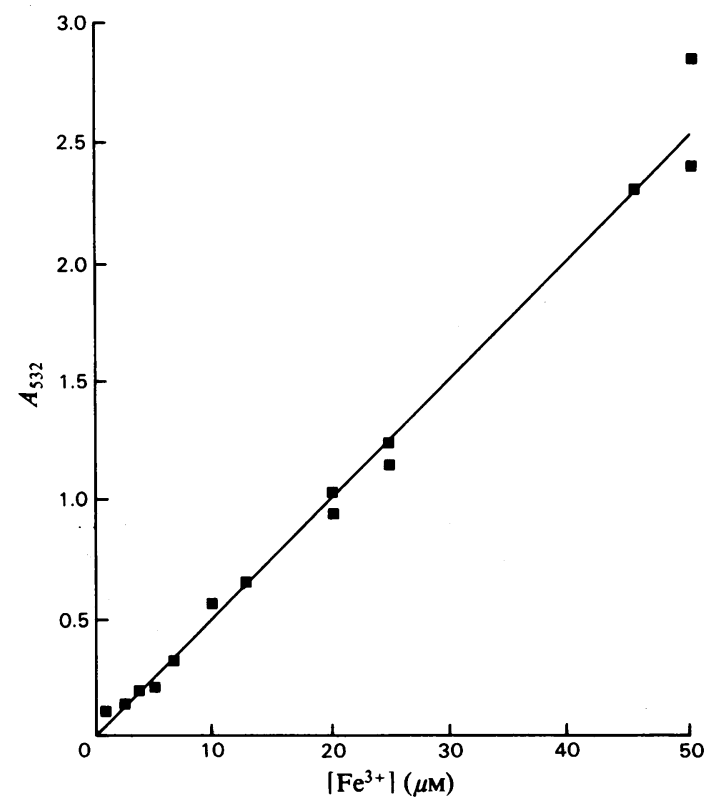

Fig. 1. Calibration of the bleomycin assay method with $\mathrm{FeCl}_{3}$

Formation of the thiobarbituric acid-reactive product was followed by its $A_{532}$ as described in the Materials and methods section, in the presence of various amounts of $\mathrm{FeCl}_{3}$. 
detected by this assay, not all of which were removed by Chelex treatment. Sterile pyrogen-free water, treated with Chelex before use, contained virtually no iron, which suggests that the iron content of ordinary distilled water may in part originate from bacteria or bacterial products such as endotoxin. Such pyrogen-free water was therefore used in all our experiments, and samples of biological fluids were collected in sterile containers. Provided that the assay procedure was followed exactly, no iron could be detected if $0.1 \mathrm{ml}$ samples of solutions of the following biological iron proteins at the concentrations stated were included in the assay mixture: haemoglobin $(1 \mathrm{mg} / \mathrm{ml})$, catalase $(50 \mathrm{mg} / \mathrm{ml})$, transferrin $0 \%$ or $100 \%$ saturated with iron $(10 \mu \mathrm{M})$, ferritin $0 \%, 20 \%$ or $100 \%$ saturated with iron $(10 \mathrm{mg} / \mathrm{ml})$, or lactoferrin $0 \%, 20 \%$ or $100 \%$ saturated with iron $(0.9 \mathrm{mg} / \mathrm{ml})$. Hence the bleomycin assay detects only 'free' iron and not iron bound to specific transport proteins or to enzymes.

\section{Presence of 'free' iron in biological fluids}

The bleomycin assay was used to detect the presence of 'free' iron, able to catalyse $\mathrm{OH}^{\text {' }}$ formation, in several fluids drawn from patients for authentic medical procedures and collected in sterile containers. Results are summarized in Table 1. No 'free' iron could be detected in plasma samples, which further shows that this assay does not pick up iron bound to transport proteins such as transferrin, which are present in plasma in abundance. Pleural-

Table 1. Presence of 'free' iron in biological fluids as assayed by the bleomycin method

Assays were performed as described in the Materials and methods section. Samples of cerebrospinal fluid were a gift from Mr. P. Lamport (Whittington Hospital, London N.19, U.K.) and samples of synovial fluid from the knees of rheumatoid patients were a gift from Dr. D. R. Blake at the Royal National Hospital for Rheumatic Diseases (Bath, U.K.). All samples had been taken for authentic medical purposes. Additions of known amounts of iron to the fluids could be quantitatively detected by subsequent assay. None of the samples was infected by bacteria.

Fluid used

Rat pleural fluid Cerebrospinal fluid

Plasma

Rheumatoid synovial 6 different patients fluid exudate fluid from rats treated with carrageenin to induce inflammation, drawn at $4 \mathrm{~h}$ and $24 \mathrm{~h}$ after injection, contained low concentrations of iron. By contrast, cerebrospinal fluid contained much greater quantities of iron, varying in a range of patients from 3.5 to $24 \mu \mathrm{M}$.

It was of particular interest to assay synovial fluid, since it has been suggested that $\mathrm{OH}^{\bullet}$ generated from $\mathrm{O}_{2}{ }^{-}$produced by phagocytes during inflammatory joint diseases is responsible for the degradation of synovial fluid that occurs in such diseases (McCord, 1974; Halliwell, 1978c; Gutteridge et al., 1979; Greenwald \& Moy, 1980). Table 1 shows that synovial-fluid samples from rheumatoid patients contains micromolar concentrations of free iron, sufficient to allow $\mathrm{OH}^{\cdot}$ formation (Halliwell, $1978 b$ ). The total iron concentration in rheumatoid synovial fluid has previously been found to be $20-40 \mu \mathrm{M}$ by atomic-absorption spectroscopy (Wong et al., 1981), as compared with 2-3 $\mu \mathrm{M}$ 'free' iron in Table 1, which indicates that most of the iron present is bound to protein complexes such as ferritin. Sufficient 'free' iron is present, however, to permit the formation of $\mathrm{OH}^{\cdot}$ from $\mathrm{O}_{2}^{-\cdot}$ and $\mathrm{H}_{2} \mathrm{O}_{2}$ generated by phagocytes in the rheumatoid joint.

We are grateful to the Wellcome Trust and to the Cancer Research Campaign for financial support, and to Dr. David R. Blake for performing the rat experiments.

\section{References}

Ambruso, D. R. \& Johnston, R. B. (1981) J. Clin. Invest. 67, 352-360

Burger, R. M., Berkowitz, A. R., Peisach, J. \& Horwitz, S. B. (1980) J. Biol. Chem. 255, 11832-11838

Dabrowiak, J. C. (1980) J. Inorg. Biochem. 13, 317-337

Diguiseppi, J. \& Fridovich, I. (1980) Arch. Biochem. Biophys. 205, 323-329

Fridovich, I. (1978) Science 201, 875-880

Greenwald, R. A. \& Moy, W. W. (1980) Arthritis Rheum. 23, 455-463

Gutteridge, J. M. C. (1979) FEBS Lett. 105, 278-282

Gutteridge, J. M. C., Richmond, R. \& Halliwell, B. (1979) Biochem. J. 184, 469-472

Halliwell, B. (1978a) Cell Biol. Int. Rep. 2, 113-128

Halliwell, B. (1978b) FEBS Lett. 92, 321-326

Halliwell, B. (1978c) FEBS Lett. 96, 238-242

Halliwell, B. (1981) in Age Pigments (Sohal, R. S., ed.), pp. 1-62, Elsevier/North-Holland Biomedical Press, Amsterdam

Haugaard, N. (1968) Physiol. Rev. 48, 311-345

McCord, J. M. (1974) Science 185, 529-531

McCord, J. M. \& Day, E. D. (1978) FEBS Lett. 86, 139-142

Wong, S. F., Halliwell, B., Richmond, R. \& Skowroneck, W. R. (1981) J. Inorg. Biochem. 14, 127-134 